\title{
STRATEGI PEMENUHAN KEBUTUHAN INFORMASI OLEH PEMUSTAKA DI PERPUSTAKAAN SEKOLAH TINGGI ILMU ISLAM DAN BAHASA ARAB (STIBA) MAKASSAR
}

\author{
Uswatul Ilmi ${ }^{1} \&$ Marni $^{1}$ \\ ${ }^{1}$ Department of Library Science, Universitas Islam Negeri Alauddin Makassar \\ Correspondence email: uswatulilmi@gmail.com
}

\begin{abstract}
Libraries must know and fulfill every information needs of their users. This descriptive study wants to find out strategies for meeting information needs and the obstacles experienced by users in meeting information needs at the Makassar Islamic and Arabic Language College Library (STIBA)? Research data obtained from informants who are users. The results of the study indicate that the STIBA library has tried to meet the information needs of its users while the constraints experienced by librarians in meeting the needs of users are budget constraints.
\end{abstract}

Keywords: Information needs; library users

\begin{abstract}
Abstrak
Perpustakaan mesti mengetahui dan memenuhi setiap kebutuhan informasi pemustakanya. Penelitian deskriptif ini ingin mencari tahu strategi pemenuhan kebutuhan informasi dan kendala yang dialami oleh pemustaka dalam memenuhi kebutuhan informasi di Perpustakaan Sekolah Tinggi Ilmu Islam dan Bahasa Arab (STIBA) Makassar? Data penelitian diperoleh dari informan yang merupakan pemustaka. Hasil penelitian menunjukkan bahwa perpustakaan STIBA telah berupaya memenuhi kebutuhan informasi pemustakanya sementara kendala yang dialami pustakawan dalam memenuhi kebutuhan pemustaka adalah keterbatasan anggaran.
\end{abstract}

Kata kunci: Kebutuhan informasi; pemustaka 


\section{Pendahuluan}

Sebagai sumber informasi, Perpustakaan adalah salah satu media yang menunjang perkembangan sebuah institusi khususnya institusi pendidikan. Dengan perkembangan teknologi yang pesat mengharuskan perpustakaan untuk tetap eksis dalam mengembangkan informasi yang terbaru. Hal ini dikarenakan kebutuhan pemustaka akan informasi semakin meningkat. Perpustakaan merupakan media peradaban yang diisi dengan berbagai jenis koleksi (buku) yang kemudian dikembangkan sesuai dengan perkembangan teknologi.

Seperti yang kita ketahui bahwa perpustakaan adalah bagian dari sebuah gedung atau ruangan yang digunakan untuk menyimpan buku dan koleksi lainnya yang susun berdasarkan kelas yang digunakan sebagai sumber informasi bagi pemustaka dan tidak untuk di perjual belikan. Adapun koleksi yang sering kita temui di perpustakaan selain buku tentunya dapat berupa terbitan berseri (majalah,jurnal ilmiah dan koran) prosiding, laporan pamflet, manuskrip, dan berbagai karya media seperti audio dan audiovisual. (Suwarno 2010:3)

Konsep informasi adalah suatu hal yang tidak dapat di defenisikan, hal tersebut dikarenakan informasi memiliki berbagai macam aspek, manfaat dan ciri yang terkadang berbeda dengan yang lain. Bisa jadi informasi hanya berupa pikiran seseorang, informasi juga dapat berisi kumpulan data yang telah diolah dan tersusun rapi, informasi adalah sebuah rekaman fenomena yang dapat diamati, dan juga bisa berupa putusan-putusan yang telah dibuat oleh orang atau sekelompok orang tertentu (Yusup,2010:1)

Pemenuhan kebutuhan informasi merupakan hak bagi setiap individu, meskipun demikian informasi yang dibutuhkan oleh setiap indivisu berbeda-beda, dalam memenuhi kebutuhan informasi setiap orang memiliki cara tertentu dalam memenuhi kebutuhan informasinya. Menurut Nicholas dalam (wardani, 2018:105). faktor yang mempengaruhi kebutuhan informasi ada sepuluh yaitu: terdiri dari faktor jenis profesi seseorang, faktor tradisi dan kebudayaan tempat orang tersebut tinggal, faktor kepribadian (dalam diri), faktor tingkat kesadaran individu seseorang akan kebutuhan informasinya, faktor jenis kelamin, faktor usia, faktor ketersediaan waktu dalam proses pencarian informasi, faktor media dalam mengakses informasi, faktor biaya yang dikeluarkan selama melakukan penelusuran informasi yang dibutuhkan, dan faktor informasi yang berlebih. Penelitian tentang pemenuhan kebutuhan informasi pemustaka, telah dilakukan oleh beberapa peneliti sebelumnya seperti, penelitian yang dilakukan oleh susriani (2014) dengan judul "Relevansi penelusuran informasi dengan kebutuhan pemustaka di Perpustakaan Universitas Islam Negeri Alauddin Makassar" dengan menggunakan metode deskriptif dengan pendekatan kuantitatif. Dengan hasil penelitian yang dilakukan di Universitas Islam Negeri Alauddin Makassar, sesuai dengan kebutuhan pemustaka atau relevan. Hal ini terbukti dari hasil penelitian sebanyak 48,8\% pemustaka yang menyatakan setuju bahwa pemenuhan kebutuhan informasi di Perpustakaan Universitas Islam Negeri Alauddin Makassar sesuai dengan koleksi yang dibutuhkan pemustaka. 
Sekolah Tinggi Ilmu Islam dan Bahasa Arab (STIBA) Makassar melalui kunjungan observasi, pemenuhan kebutuhan informasi mahasiswa ada beberapa hal yang tidak sesuai dengan kemampuan mahasiswa seperti kebutuhan mahasiswa alumni Sekolah Menengah Atas (SMA) sedikit kesulitan dalam memenuhi kebutuhan informasi dikarenakan koleksi Perpustakaan Sekolah Tinggi Ilmu Islam dan Bahasa Arab (STIBA) Makassar 80\% koleksi perpustakaannya menggunakan bahasa dokumen berbahasa arab sedangkan mahasiswa alumni Sekolah Menengah Atas (SMA) tidak memiliki dasar bahasa tersebut.

Disamping itu koleksi Perpustakaan Sekolah Tinggi Ilmu Islam dan Bahasa Arab (STIBA) Makassar terbatas, dikarenakan mereka hanya melakukan pengadaan bahan pustaka apabila ada sumbangan dari pihak tertentu, tidak melakukan pengadaan seperti yang seharusnya dilakukan perpustakaan pada umumnya. Salah satu fungsi Perpustakaan Sekolah Tinggi Ilmu Islam dan Bahasa Arab (STIBA) Makassar adalah sebagai media untuk memenuhi kebutuhan informasi baik, itu bagi mahasiswa, dosen, maupun staf-staf yang terlibat pada sivitas akademi tersebut.

Untuk menunjang pembelajaran kelas mahasiswa perlu melakukan penelusuran informasi yang relevan sehingga tercipta kesesuaian dalam menelusuri informasi dan memahami informasi sesuai dengan kebutuhan, dengan demikian tidak terjadi kesalahan dalam mengerjakan tugas yang telah diberikan oleh pengajar/dosen. Di Sekolah tinggi Ilmu Islam dan Bahasa arab itu sendiri terdiri atas dua Program Studi yaitu: S1 syariah Program Studi Perbandingan Mazhab dan Program I'dad lughawiyah

Secara umum penelitian ini bertujuan untuk mengetahui strategi pemenuhan kebutuhan informasi oleh pemustaka yang memiliki latar belakang pendidikan Sekolah Menengah Atas (SMA) di Perpustakaan Sekolah Tinggi Ilmu Islam Dan Bahasa Arab (STIBA) Makassar dan Untuk mengetahui kendala yang dialami pemustaka yang memiliki latar belakang pendidikan Sekolah Menengah Atas (SMA) dalam memenuhi kebutuhan informasi di Perpustakaan Sekolah Tinggi Ilmu Islam dan Bahasa Arab (STIBA) Makassar.

\section{Metodologi}

Metode penelitian kualitatif dengan pendekatan deskriptif adalah metode penelitian yang digunakan Penelitian kualitatif memiliki sifat sementara, artinya dapat dikembangkan atau diubah setelah peneliti turun langsung kelapangan. Metode penelitian kualitatif dengan pendekatan deskriptif adalah suatu rumusan masalah yang membimbing peneliti untuk memotret dan menyurvei keadaan sosial secara keseluruhan, merata dan detail. (Sugiyono, 2010: 283)

Pada penelitian ini, peneliti akan berusaha mengeksplor data deskriptif secara keseluruhan yang berupa hasil observasi, wawancara, data tertulis yang mendukung. Untuk merealisasikan hal tersebut peneliti turun langsung kelapangan untuk mendapatkan data-data serta fakta tentang strategi pemustaka dalam memenuhi kebutuhan informasi di Perpustakaan Sekolah Tinggi Ilmu Islam dan Bahasa Arab (STIBA) Makassar. 
Sumber data yang diperoleh menggunakan sumber data primer dan sumber data sekunder

a. Data primer

Data primer adalah sumber data yang diperoleh melalui wawancara dan observasi langsung yang dilakukan oleh peneliti untuk mendapatkan data yang valid. Disebut data primer karena data ini merupakan data utama dalam penelitian. Yang menjadi informan dalam penelitian ini adalah pustakawan (staf perpustakaan) dan pemustaka yang berkunjung ke Perpustakaan Sekolah Tinggi Ilmu Islam dan Bahasa Arab (STIBA) Makassar khususnya pemustaka yang memilki latar belakang pendidikan Sekolah Tinggi Menengah Umum.

b. Data sekunder

Data sekunder adalah data yang menunjang data utama atau data primer. Data sekunder dapat diperoleh dari berbagai sumber seperti halaman website, buku panduan, dan dokumen yang berhubungan dengan pembahasan penelitian ini. Menggunakan teknik pengumpulan data observasi, wawancara dan dokumentasi

\section{c. Observasi}

Menurut Nasution dalam Sugiyono, observasi adalah dasar sebuah ilmu pengetahun, para peneliti dapat mengemukakan sebuah teori berdasarkan data, yaitu fakta yang dilihat dan diamati mengenai dunia nyata yang diperoleh melalui observasi dan pengamatan. Data tersebut kemudian dikumpulkan kemudian seiring dengan perkembangan tekenologi dibantu dengan berbagai alat sehingga benda-benda yang sangat kecil (seperti proton dan elektron) maupun yang sangat jauh (benda luar angkasa) dapat diamati dengan jelas untuk disimpulkan menjadi sebuah teori dan ilmu pegetahuan.

d. Wawancara

Wawancara merupakan suatu tindakan dimana terdapat komunikasi antara pewawancara dan informan untuk menggali suatu hal yang ingin dirancang agar terjadi proses tanya jawab. (Hakim, 2013:167)

Pada penelitian ini dilakukan wawancara yang sifatnya berstruktur, artinya wawancara yang dilakukan secara tersusun dalam artian pewawancara terlebih dahulu penyusun pedoman-pedoman tercatat mengenai pertanyaan-pertanyaan yang akan diajukan kepada informan atau narasumber. Dari awal hingga akhir hal ini yang menjadi pedoman wawancara. (Bungin, 2013: 134-135)

\section{e. Dokumentasi}

Pengumpulan data menggunakan metode ini memudahkan peneliti dalam mendapatkan data yang relevan. Dengan adanya data-data tersebut dapat menunjang terlaksananya penelitian ini sehingga dapat diuraikan keabsahan, dan kemurnian. kemudian penelitian ini dapat dipertanggungjawabkan.

Instrumen penelitian dalam penelitian kualitatif tak lain adalah peneliti itu sendiri selanjutnya akan turun ke lapangan untuk melakukan observasi, wawancara, mengumpulkan data, dan dokumentasi.

Menurut Nasution dalam Sugiyono (2010;307) sebagai intrumen penelitian, peneliti hal-hal yang harus diperhatikan: 
a. Peneliti harus cepat tanggap terhadap lingkungan sekitar yang diperkirakan berfungsi untuk penelitian atau tidak.

b. Sebagai alat, peneliti mampu menyesuaikan diri terhadap lingkungan dan dapat menggalang berbagai macam data sesuai dengan kebutuhan.

c. Sebagai instrumen peneliti tidak menggunakan alat seperti angket

d. Melipatkan interaksi antarmanusia. Dalam interaksi tersebut komunikasi yang dilakukan berkesinambungan dengan ruang lingkup penelitian dan mudah dipahami.

e. Menganalisis data yang diperoleh dan membuat kesimpulan adalah tugas peneliti sebagai instrumen untuk menghasilkan suatu hipotesis dalam menentukan langkah selanjutnya yang akan dilakukan

f. Peneliti sebagai instrumen dapat mengambil kesimpulan berdasarkan data yang didapatkan di lapangan untuk mendapatkan penegasan, perubahan, dan koreksi.

g. Jika metode penelitian kuantitatif menggunakan angket sebagai intrumn maka, yang diperhatikan hanya respon yang diakuntifisi agar dapat diolah secara statistik sedangkan metode penelitian kualitatif memperhatikan semua jenis respon untuk mengolah data.

h. Teknik analisis data dilakukan untuk menjawab rumusan masalah atau menguji hipotesis yang telah terstruktur dalam metode penelitian kualitatif. Teknik analisis data tersebut dilakukan dengan metode statistik yang telah tersedia hal ini dilakukan karena datanya kualitatif.

Analisis data kualitatif bersifat induktif artinya suatu analisis yang didapatkan berdasarkan data-data yang didapatkan, setelah itu dikembangkan untuk mendapatkan suatu hipotesis. Kemudian berdasarkan hipotesis dari data tersebut. Untuk memastikan apakah hipotesis tersebut dapat diterima atau ditolak berdasarkan data yang terkumpul maka, perlu dilakukan penjabaran. Jika hipotesis yang telah dikumpul berdasarkan data yang telah diterima maka, hipotesis tersebut dapat berkembang menjadi sebuah teori.

Analisis data dapat dilakukan dengan beberapa cara yaitu:

a. Reduksi kata

Data yang didapatkan dari lapangan berdasarkan hasil pengamatan yang jumlahnya cukup banyak perlu difilter atau diseleksi seperti yang dikemukakan bahwa semakin banyak data yang maka akan semakin sulit maka untuk mengatasi hal tersebut maka peneliti mereduksi kata agar mudah dirangkum untuk memperoleh data-data utama yang berhubungan dengan bidang penelitian yang dilakukan sehingga mempermudah peneliti untuk melanjutkan langkah selanjutnya dan mudah ditemukan bila diperlukan.

b. Penyajian data

Setelah tahap reduksi kata selanjutnya adalah penyajian data, dalam penyajian data ini peneliti akan menghubungkan temuan-temuan baru dangan data-data yang telah ada sebelumnya. Penyajian data ini dilakukan untuk menemukan hal-hal menarik 
dari masalah yang diperoleh, metode yang digunakan, penemuan yang diperoleh, kesimpulan yang didapatkan dan dijabarkan dalam teori.

c. Kesimpulan dan verifikasi

Menurut Miles and Huberman dalam Sugiyono (2010;345) kesimpulan awal yang didapatkan dalam metode penelitian kualitatif sifatnya masih sementara dan dapat berubah sewaktu-waktu apabila bukti tidak di temukan untuk mendukung dan memperkuat proses pengumpulan data berikutnya. Akan tetapi apabila kesimpulan yang didapatkan pada tahap awal dapat dibuktikan dengan data data yang kuat dan sesuai saat peneliti kembali terjun ke lapangan maka kesimpulan yang disajikan merupakan kesimpulan yang kredibl.

Pada dasarnya pada penelitian kualitatif dapat dapat menjawab rumusan masalah yang dirumuskan bisa juga tidak, karena seperti yang telah dikemukakan bahwa masalah dalam rumusan masalah kualitiatif masih bersifat sementara dan akan berkembang setelah peneliti kembali kelapangan untuk mendapatkan bukti yang kuat.

\section{Hasil dan Pembahasan}

Perpustakaan Sekolah Tinggi Ilmu Islam dan Bahasa Arab (STIBA) Makassar adalah salah satu perpustakaan perguruan tinggi yang menggunakan OPAC (Online Acces Catalogue) sebagai media untuk memudahkan pemustaka dalam menelusuri koleksi koleksi bahan pustaka. Pada penelitian ini akan diuraikan hasil penelitian tentang strategi pemenuhan kebutuhan informasi pemustaka khususnya pemustaka yang memiliki latar belakang pendidikan Sekolah Menengah Atas (SMA) di Perpustakaan Sekolah Tinggi Ilmu Islam dan Bahasa Arab (STIBA) Makassar.

Sebagai salah satu unit yang berperan penting dalam pemenuhan kebutuhan informasi perpustakaan Sekolah Tinggi Ilmu Islam dan Bahasa Arab (STIBA) Makassar, maka Pustakawan ataupun staf Perpustakaan di Perpustakaan Sekolah Tinggi Ilmu Islam dan Bahaba Arab (STIBA) Makassar berupaya memenuhi kebutuhan informasi pemustaka khususnya pemustaka yang memiliki latar belakang pendidikan Sekolah Menengah Atas (SMA). Berdasarkan hasil penelitian yang dilakukan oleh peneliti melalui observasi, wawancara dan dokumentasi sebagai proses pengumpulan data, setelah selesai pada proses pengumpulan data, selanjutnya peneliti melanjutkan pada tahap pengolahan data dengan analisis data secara deskriptif tentang pemenuhan kebutkan informasi pemustaka khususnya pemustaka yang memiliki latar belakang pendidikan Sekolah Menengah Atas (SMA) di Perpustakaan Sekolah Tinggi Ilmu Islam dan Bahasa Arab (STIBA) Makassar.

Berdasarkan hasil wawancara dapat digambarkan bahwa pemenuhan kebutuhan informasi pemustaka menjadi prioritas untuk menunjang kebutuhan pemustaka. Dalam menelusuri informasi setiap pemustaka memiliki tingkat kebutuhan informasi yang berbeda tergantung kebutuhan lingkungan, pekerjaan atau kebutuhan lain. Untuk memenuhi kebutuhan informasi pemustaka perpustakaan perlu memperhatikan ketersediaan koleksi. Dari beberapa pernyataan tersebut yang menjadi kendala dalam menggunakan koleksi yang ada di perpustakaan bagi 
pemustaa yang memiliki latar belakang pendidikan sekolah menengah atas (SMA) adalah kurangnya pengetahuan kosakata dan dasar-dasar penggunaan bahasa Arab yang dikuasai oleh pemustaka yang memiliki latar belakang pendidikan Sekolah Menengah Atas di Perpustakaan Sekolah Tinggi Ilmu Islam dan Bahasa Arab (STIBA) Makassar.

\section{a. Strategi pemenuhan kebutuhan informasi oleh pemustaka yang memiliki latar belakang pendidikan Sekolah Menengah Atas (SMA) di Perpustakaan Sekolah Tinggi Ilmu Islam Dan Bahasa Arab (STIBA) Makassar}

\section{Strategi Pengadaan Koleksi Bahan Pustaka}

Menurut Sumantri (Sumatri 2002:29) pengadaan bahan kegiatan pengadaan bahan pustaka pada suatu Perpustakaan terikat pada rambu-rambu yang menjadi prioritas pengadaan bahan pustakaan yang telah ditentukan dalam kebijakan pengembangan koleksi. Pengadaan bahan pustaka adalah bagian dari pengembangan koleksi pada umumnya setiap perpustakaan mengadakan pengadaan bahan pustaka hanya saja cara pengadaan bahan pustaka berbeda-beda setiap perpustakaan tergantung jenis perpustakaan dan kebijakan instansi yang menaungi.

Sebagai suatu perguruan tinggi yang berada di bawah Naungan Yayasan Wahdah Islamiyah Perpustakaan Sekolah Tinggi Ilmu Islam dan Bahasa Arab (STIBA) Makassar melakukan pengadaan bahan pustaka dengan cara melakukan pendataan tentang koleksi yang paling banyak dibutuhkan oleh pemustaka kemudian melakukan pembelian koleksi ataupun permintaan koleksi bahan pustaka kepada donatur kemudian untuk memenuhi kebutuhan informasi pemustaka yang memiliki latarbelakang pendidikan Sekolah Menengah Atas (SMA) yaitu dengan mengadakan bahan pustaka yang menggunakan Bahasa dokumen Bahasa Indonesia.

Pengadaan bahan pustaka itu sendiri tidak diadakan secara rutin di Perpustakaan Sekolah Tinggi Ilmu Islam dan Bahasa Arab (STIBA) Makassar, hanya diadakan pengadaan bahan pustaka apabila ada dana atau anggaran tidak dilakukan secara berkala. sebagai gantinya pihak perpustakaan menyediakan akses internet untuk memenuhi kebutuhan informasi pemustaka apabila informasi yang dibutuhkan pemustaka tidak tersedia di perpustakaan selain pengadaan bahan pustaka yang berbahasa Indonesia pihak perpustakaan juga mengadakan bahan pustaka berupa kamus bahasa arab terbitan dalam negeri.

Sumber koleksi bahan pustaka di perpustakaan Sekolah Tinggi Ilmu Islam dan Bahasa Arab (STIBA) Makassar tidak hanya melalui proses pembelian bahan pustaka beberapa koleksi merupakan sumbangan dari donatur maupun sumbangan dari alumni. Alumni yang paling banyak menyumbang koleksi ke Perpustakaan Sekolah Tinggi Ilmu Islam dan Bahasa Arab (STIBA) Makassar adalah Alumni yang melanjutkan pendidikan di Timur Tengah. Koleksi-koleksi yang disumbangkan 
berupa buku dari berbabagi macam bidang keilmuan islam seperti fiqh qawa'idh (kaidah-kaidah fiqih) Fiqih Ibadah, Fiqih Wanita, Aqidah Akhlak, Kitab Tauhid, Ilmu Nahwu dan Sharaf, dan buku-buku Tafsir diantara buku yang disumbangkan tersebut terdapat beberapa buku terbitan dari universitas Ummul-Qura', koleksi tersebut diperuntukkan untuk program studi Perbandingan Mazhab sebagai sumber informasi, sedangkan sumber informasi untuk program studi i'dadh lughawiyah disediakan beberapa eksamplar kamus dan buku Nahwu dan Sharaf sebagai panduan penggunaaan kaidah Bahasa Arab.

\section{Strategi pelatihan bahasa}

Pihak Sekolah Tinggi Ilmu Islam dan Bahasa Arab (STIBA) Makassar bekerjasama dengan pihak perpustakaan melakukan pelatihan bahasa arab bagi mahasiswa khususnya mahasiswa yang memilki latar belakang pendidikan Sekolah Menengah Atas (SMA). Hal tersebut dilakukan agar mahasiswa yang memilki latar belakang pendidikan Sekolah Menengah Atas mampu menggunakan bahasa Arab dalam proses belajar mengajar maupun dalam kehidupan sehari-hari. Pelatihan tersebut rutin dilakukan tiga atau empat kali dalam satu minggu setiap tahun ajaran baru hal tersebut dilakukan untuk melatih mahasiswa yang memiliki latar belakang Pendidikan Sekolah Menengah Atas untuk terbiasa menggunakan Bahasa Arab dalam Kehidupan Sehari-hari maupun pembelajaran dalam kelas.

\section{b. Kendala yang dialami oleh pemustaka yang memiliki latar belakang pendidikan Sekolah Menengah Atas (SMA) untuk memenuhi kebutuhan informasi di Perpustakaan Sekolah Tinggi Ilmu Islam dan Bahasa Arab (STIBA) Makassar}

\section{Keterbatasan berbahasa}

Keterbatasan dalam penggunaan Bahasa menjadi kendala utama bagi mahasiswa yang memilki latarbelakang Pendidikan Sekolah Menengah untuk mengakses informasi dalam hal ini diantara beberapa pemustaka tersebut melakukan berbagai upaya untuk memenuhi kebutuhan informasi mereka seperti mencari kosakata yang ada pada kamus yang telah disiapkan oleh pihak perpustakaan, mempelajari kaidahkaidah bahasa menggunakan buku yang disediakan oleh pihak perpustakaan seperti buku nahwu dan sharaf, bertanya kepada teman atau sesama pemustaka yang memiliki pengetahuan Bahasa Arab yang lebih mahir, atau bertanya langsung kepada petugas perpustakaan secara langsung tentang makna atau isi dari sebuah koleksi, petugas sendiri bersedia membantu pemustaka dalam menerjemahkan atau memaknai sebuah buku hal, tersebut dilakukan sebagai salah satu cara pemenuhan 
kebutuhan informasi pemustaka, khususnya pemustaka yang memilki latar belakang Pendidikan Sekolah Menengah Atas (SMA).

\section{Keterbatasan Koleksi Berbahasa Indonesia}

Koleksi perpustakaan di Perpustakaan Sekolah Tinggi Ilmu Islam dan Bahasa Arab (STIBA) Makassar berjumlah 2498 judul dengan 1975 eksamplar hanya saja koleksi yang menggunakan bahasa dokumen bahasa indonesia sangat minim yaitu sekitar 80 $\%$ termasuk karya ilmiah berupa skripsi hal tersebut yang membuat pemustaka yang memililiki latar belakang pendidikan Sekolah Menengah Atas (SMA) kesulitan dalam menggunakan koleksi yang disediakan oleh pihak Perpustakaan. Namun, mereka tetap menggunakan koleksi perpustakaan sebagai bahan untuk belajar berbahasa seperti menggunakan kamus untuk memperbanyak mufradat (kosakata Bahasa Arab), menggunakan buku kaidah-kaidah penggunaan bahasa Arab untuk mengetahui kaidah-kaidah penggunaan Bahasa Arab.

Pada dasarnya pihak perpustakaan Sekolah Tinggi Ilmu Islam dan Bahasa Arab (STIBA) Makassar baik kepala perpustakaan maupun pustakawan ingin melakukan pengadaan bahan pustaka secara berkala baik itu setiap tiga bulan sekali, enam bulan sekali atapun setahun sekali hanya saja anggaran tidak memungkinkan.

\section{Kesimpulan}

Strategi pemenuhan kebutuhan informasi pemustaka yang memiliki latar belakang pendidikan Sekolah Menengah Atas (SMA) di Perpustakaan Sekolah Tinggi Ilmu Islam dan Bahasa Arab (STIBA) Makassar yaitu : dengan mengadakan pelatihanpelatihan bahasa, memperbanyak koleksi bahan pustaka yang menggunakan bahasa dokumen bahasa Indonesia, Namun koleksi yang berbahasa Indonesia di Perpustakaan Sekolah Tinggi Ilmu Islam dan Bahasa Arab (STIBA) Makassar, dan melakukan alih media koleksi dalam bentuk pdf sehingga dapat dibagikan secara online kepada pemustaka Selain itu strategi pemenuhan kebutuhan informasi pemustaka dengan pengadaan koleksi yang berasal dari sumbangan berupa koleksi buku-buku fiqh, qawaidh fiqh,ushul fiqh, kitab tauhid dan beberapa buku yang diterbitkan di universitas ummul Qura'. Selain itu disediakan beberapa kamus dan buku nahwa dan sharaf sebagai sumber informasi bagi mahasiswa i'dadh lughawiyah untuk memahami penggunaan Bahasa Arab.

Kendala yang dihadapi oleh pemustaka yang memiliki latar belakang pendidikan Seekolah Menengah Atas (SMA) yaitu keterbatasan kosa kata bahasa Arab dan keterbatasan penggunaan kaidah-kaidah bahasa arab khususnya untuk koleksi bahan pustaka yang memiliki tingkat bahasa arab yang tinggi. Misalnya pada koleksi-koleksi bahasa Arab yang tidak menggunakan harakat maka, pemustaka kesulitan dalam membaca dan menerjemahkan koleksi tersebut ataupun koleksi bahasa arab yang 
menggunakan harakat namun, memiliki pembendaharaan bahasa arab yang rumit sehingga sulit untuk diterjemahkan hanya dengan menggunakan kamus harus menggunakan buku pendukung yaitu buku penggunaan kaidah-kaidah bahasa Arab. 


\section{References}

Fatmawati, Endang. 2015. "Kebutuhan Informasi Pemustaka Dalam Teori Dan Praktek." Persadha:Media Informasi Perpustakaan Universitas Sanaat Dharma Vol 13 No.1

Koswara. 1998. Dinamika Informasi Di Era Global. Bandung : IPI Jawa Barat Dan Remaja Rosdakarya.

Muin, Azwar. 2014. Information Literacy Skills. Makassar: Alauddin University Press.

Rismayeti. 2013. "Perpustakaan Peerguruan Tinggi: Pedoman, Pengelolaan An Standardisasi." Jurnal Ilmu Budaya". Vol 9 No 2.

Sekolah Tinggi Ilmu Islam dan Bahasa Arab Makassar. 2020. Panduan Pelayanan Teknis Perpustakaan Tahun 2020. Makassar.

Sulistyo-Basuki. 1993. Pengantar Ilmu Perpustakaan. Jakarta: Gramedia Pustaka.

Sulstyo-Basuki. 2004. Pengantar Dokumentasi: Mulai Dari Perkembangan, Istilah Pemahaman Jenis Dokumen, Diikuti Dengan Pengolahan Dan Temu Kembali Dokumen, Disusul Teknologi Komunikasi Dan Komunikasi Dampai Dengan Jasa Pemencaran Informasi Serta Diakhiri Dengan Etika Profesi. Bandung: Rekayasa Sains.

Suwarno, Wiji. 2010. Pengetahuan Dasar Kepustakaan: Sisi Pentning Perpustakaan Dan Pustakawan. Bogor: Ghalia Indonesia.

Tawaf, Dan Khaidir Alimin . 2012. "Kebutuhan Informasi Manusia: Sebuah Pendekatan Kepustakaan.” Jurnal Prerpustakaan Dan Ilmu Informasi" Vol 15 NO.1

UIN Alauddin Makassar. 2013. Pedoman Penulisan Karya Ilmiah: Makalah, Skripsi, Tesis, Disertasi, Dan Laporan Penelitian. Makassar: Alauddin Press.

Wardani, Tri Rahma Kusuma, Tri Rahma Kusuma Wardani, Hery Siwignyo, Dan Dwi Novita Ernaningsih. 2018. "Kebutuhan Informasi Dan Upaya Pemenuhan Kebutuhan Informasi Pada Komunitas Tuli." BIBLIOTIKA: Jurnal Kajian Perpustakaan Dan Informasi" Vol 2 No.2

Yusup, Pawit M., Dan Priyo Subekti. 2010. Teori Dan Praktik Pnelusuran Informasi : Information Rtrieval. Jakarta: Kencana 